\title{
CONCEPT OF PERSONNEL MANAGEMENT OF CONSTRUCTION ENTERPRISES \\ UNDER THE CONDITIONS OF INNOVATIVE ACTIVITY BASED ON THE AWARENESS OF SPECIFIC FEATURES OF THE INDUSTRY
}

\section{Khrystyna Kalashnikova ${ }^{1}$ Viktoriia Shcevchenko}

DOI: https://doi.org/10.30525/978-9934-588-15-0-30

Abstract. The article proves that an effective personnel management process should be based on taking into account the characteristics of the enterprise, its production and commercial process, goods and services, manufactured and sold goods. In order to clarify the conceptual provisions of the personnel management of construction enterprises, the specifics of the construction industry, construction products and services were investigated. Determining the specifics of a product requires the development of a well-considered product policy (proposal), which will be supported by other elements of the marketing mix. Thus, for the development of the construction industry should take into account the interests and needs of all participants in production and promotion, their relationship. Development should begin at each individual enterprise, while it should be borne in mind that it is highly qualified and motivated personnel that is one of the main reserves of construction enterprises in the production of complex products. The effectiveness of the activities of both an individual construction company and the entire industry depends on effective personnel management. The increased attention to innovations and innovative processes at all levels of human activity necessitated the study of priority areas for the innovative development of the construction industry, the main of which are: standardization and rationing in construction, training of highly qualified scientific

\footnotetext{
${ }^{1} \mathrm{PhD}$ in Economics,

Associate Professor of the Department of Management and Public Administration, O.M. Beketov National University of Urban Economy in Kharkiv, Ukraine

${ }^{2} \mathrm{PhD}$ in Economics,

Associate Professor of the Department of Management and Public Administration,

O.M. Beketov National University of Urban Economy in Kharkiv, Ukraine

(C) Khrystyna Kalashnikova, Viktoriia Shcevchenko
} 
personnel in the fields of construction, architecture, urban planning and the building materials industry, development of new and improvement of existing projects of building structures for buildings and servation of different purposes, the effect of conventional and complex etc. enerno and geological conditions, the solution of issues related to economic development and production of building structures and the like. At the same time, not only technical innovations should be used, but also innovations in the management, in particular, of personnel. The introduction of innovative methods of personnel management will allow the construction company to provide a greater volume and quantity of innovations in products, due to more efficient use of the potential, knowledge and skills of its own personnel. Awareness of the need to improve the personnel management process of construction enterprises necessitated an analysis of existing approaches and concepts of personnel management. The analysis made it possible to propose an author's personnel management system for construction enterprises in the conditions of innovative activity, which is based on a humanistic approach to personnel management. The structural model of the organization of effective personnel management of the construction organization is built. It is proved that building an effective personnel management system, a good choice of concept, motivation, management methods and style, providing the enterprise with human resources, their rational use, a high level of labor productivity contribute to an increase in production volumes, the efficient use of equipment, equipment, machinery, mechanisms, reduction cost and projected on the result of the enterprise and its profit. It is such a personnel management system of a construction enterprise that should lead to an increase in the innovation activity of the enterprise itself.

\section{Introduction}

The construction industry is one of the most important sectors of the national economy, on which the effectiveness of the functioning of the entire economic system in the country depends. The importance of this industry for the economy of any country can be explained as follows: capital construction, probably like no other industry, creates a large number of jobs and consumes the products of many sectors of the economy. The economic effect of the development of this industry lies in the multiplier effect of the funds invested in construction. Indeed, with the development 
of the construction industry, the following will develop: the production of building materials and related equipment, the machine-building industry, metallurgy and metalworking, petrochemistry, glass production, the woodworking and porcelain industry, transport, energy, etc. And, obviously, like no other industry, construction contributes to the development of small businesses, especially one that specializes in finishing and repair work, in the production and installation of built-in furniture ate, etc.

The significance and role of the construction industry is determined by its participation in the expanded reproduction of fixed assets of the country's national economy sectors, improvement of the industrial structure and location of enterprises, attraction of newly discovered natural resources in the production, integrated development of the country's economy, economic regions, implementation of urban planning and rural development programs, creating the basis for the material and cultural standard of living of the people.

In the conditions of the formation of market relations in Ukraine, processes of decentralization of enterprise management and their independent development took place. This requires the heads of enterprises to make independent decisions, and in conditions of intense competition. To achieve competitive advantages, the employee of the enterprise should be considered as the most important factor of production and resource. Under such conditions, personnel management becomes one of the main links in enterprise management and the basis of its innovation.

The aim of the article is to determine the concept of personnel management of construction enterprises, taking into account the specific features and features of the construction industry, which have a direct impact on construction enterprises, which are at the stage of innovative development and are innovatively oriented in their own activities.

\section{The main subjects of construction}

The economic effect of the development of the construction industry is the multiplier effect of the funds invested in construction. Indeed, with the development of the construction industry, the following will develop: the production of building materials and related equipment, the engineering industry, metallurgy and metalworking, petrochemicals, glass production, the woodworking industry, transport, energy, etc. And, obviously, like 
no other economic sector, construction contributes to the development of enterprises small businesses, especially those specializing in finishing and repair work, in the production and installation of built-in furniture, etc. That is, they perform certain work and produce goods consumed by construction companies and their clients. Due to the fact that the relations in the construction industry are constantly changing and developing, the list of construction entities is changing. Con-struction is of a network nature, due to the multiplicity of interconnections of entities (design, commercial, technological, state, etc.). The legislation in the field of the construction industry does not clearly define and describe the list of construction entities, their hierarchy, and definitions. But we can distinguish the main actors involved

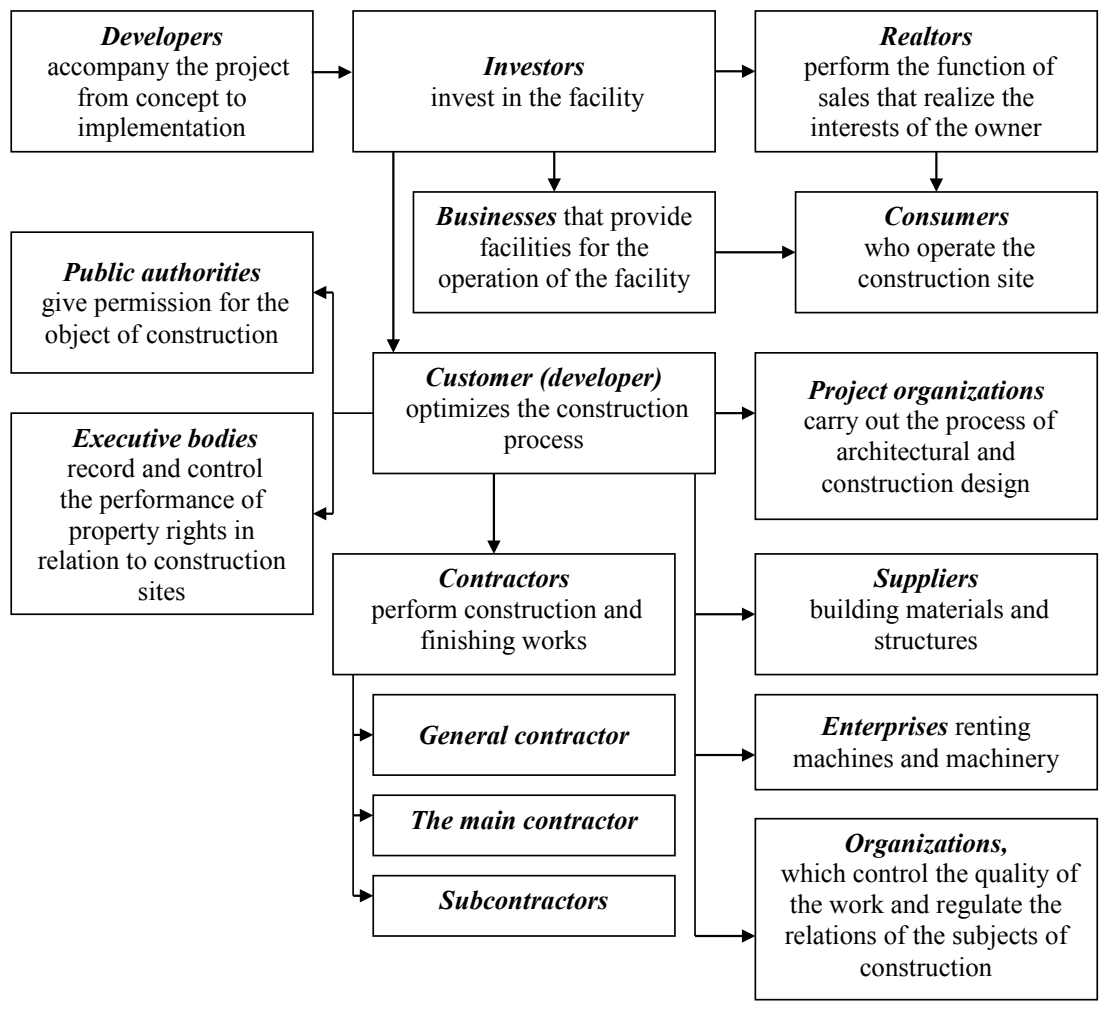

Figure 1. The process of interaction of the main subjects of construction 
in the construction. The process of interaction of the main subjects of construction can be represented as follows (Figure 1).

Based on the foregoing, we can conclude that construction is a complex process that includes many participants and performers. At the same time, there is a need for highly qualified personnel who can effectively carry out all stages of construction.

A large number of construction participants, which determines the complexity of the final product, is one of the specific features of the industry.

\section{Construction industry specifics}

Construction has specific features that distinguish it from other branches of material production. Construction products are stationary and territorially fixed. In this regard, after completion of work at one facility, tools and workers move to another facility. The construction is characterized by a relatively long duration of the production cycle, a significant variety of buildings, constructed structures and objects of various industrial and social purposes, a significant impact on the production process of geographical, in particular climatic, conditions. Construction covers all regions of the country. Powerful construction organizations have been created in large cities. A large volume of various construction works is performed by power engineers: design and survey institutes of a branch profile (ferrous metallurgy, chemistry, etc.) have been created.

Three concepts should be distinguished, which are defined by the term "construction" (Figure 2).

In countries with developed market economies, the construction industry is developing according to the laws of the market and is subject to market conditions and fluctuations in the economic cycle. A characteristic feature of the market form of organization and management of construction activities is the existence of competitive relations. Competition acts as the main stimulus to the development of innovative processes in the industry and to increase the efficiency of functioning of the construction industry. At the same time, construction has its own characteristic features that distinguish it from other industries and dictate the need for specific forms of organization and management of construction production (Figure 3).

According to a number of features, construction differs significantly from other sectors of the national economy. This industry is characterized 


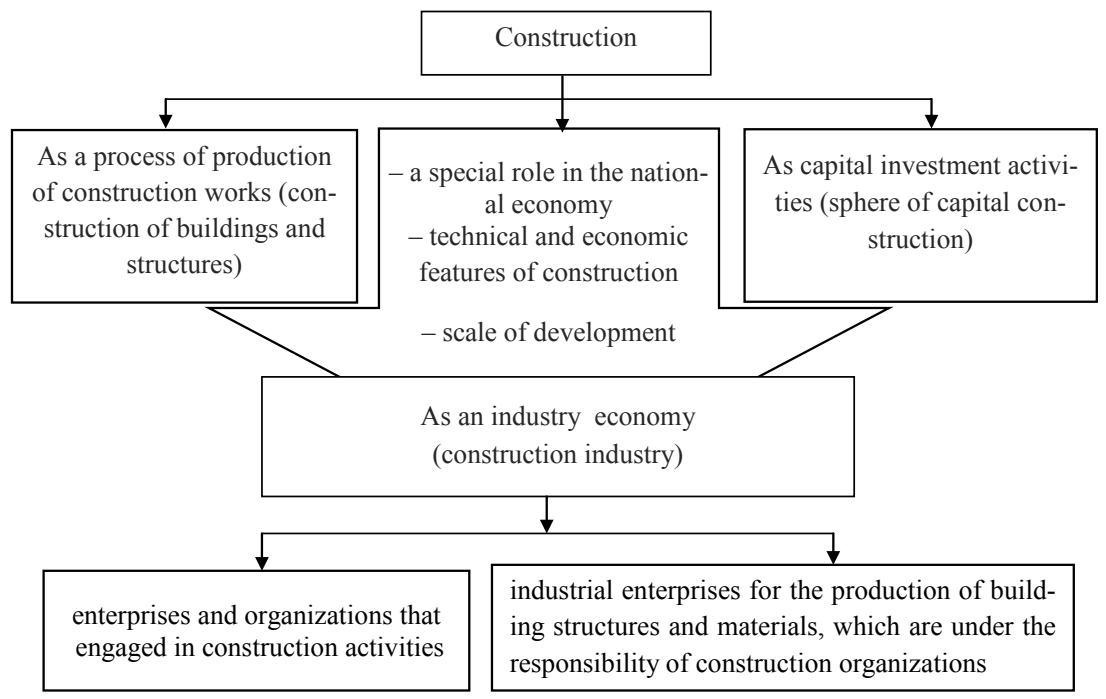

Figure 2. Construction as an independent branch of the economy

by a diverse structure of contracting construction organizations and enterprises, a high level of their specialization and cooperation. It is one of the most highly monopolized sectors in the structure of the national economy of Ukraine. In terms of production and the number of employees employed, the construction industry occupies almost a tenth of the Ukrainian economy.

The importance and role of the construction industry is determined by its participation in the expanded reproduction of fixed assets of all sectors of the national economy, improvement of the sectoral structure and location of enterprises, attraction of newly discovered natural resources to the production, integrated development of the country's economy, economic regions, implementation of urban planning and rural development programs creating the basis for the material and cultural standard of living of the people.

\section{The specificity of construction products as goods}

The complexity and diversity of production in the construction industry covers various objects - from single-family houses to large industrial enterprises and engineering structures. The technology of construction work is constantly being improved. 


\section{Chapter «Economic sciences»}

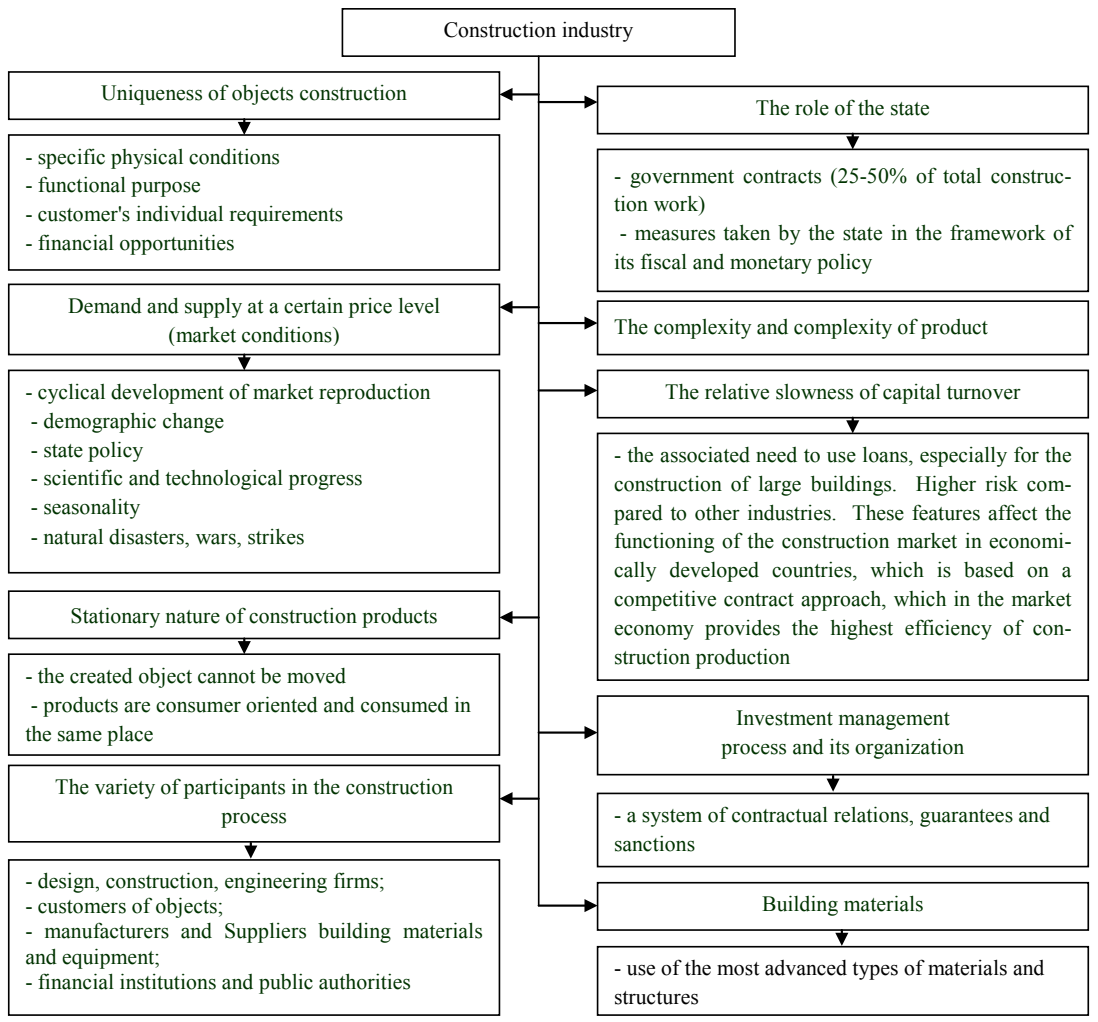

\section{Figure 3. Specific Features of the Construction Industry}

A product (service) is everything that can satisfy a need or need and is offered to the market in order to attract attention, purchase, use or consumption. It can be physical objects, persons, places, organizations, ideas [2].

The difference between construction products as goods in relation to all types of mass and mass production goods requires a different approach to studying market problems. In this case, competition between firms is considered, not for what was produced by construction, design, manufacturing enterprises, but for construction products (finished buildings and structures for civil or industrial purposes, building structures and building materials), which are accompanied by additional services in the form of guarantees, con- 


\section{Khrystyna Kalashnikova, Viktoriia Shcevchenko}

sultations, financing, delivery features, and are of interest to the consumer (ecologically clean areas, a prestigious area will allow At the same costs for the construction of facilities and its operation receive high revenues) [4].

Construction products are not unambiguously defined. The main types, features and promotion of construction products are presented in figure 4 .

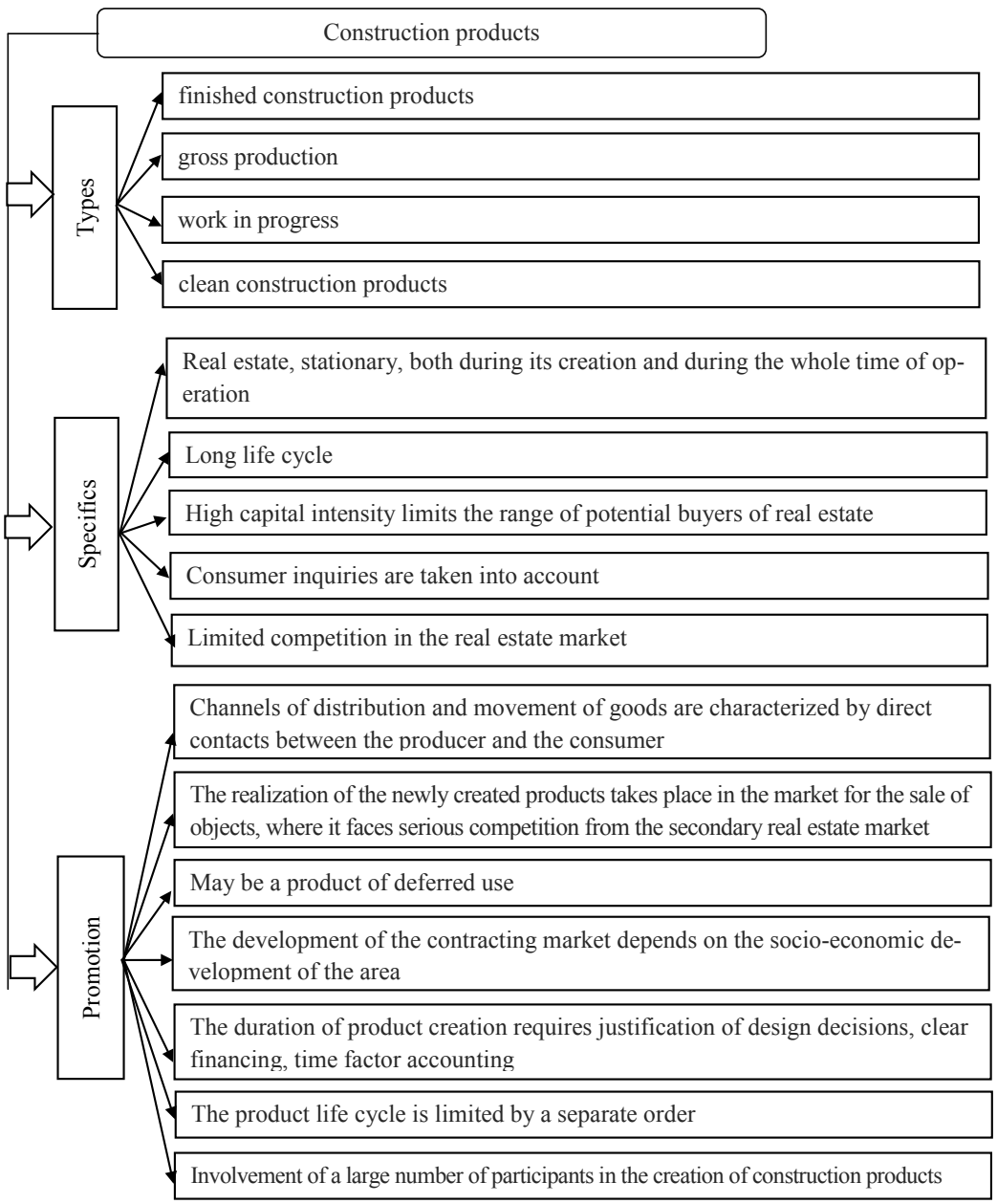

Figure 4. The specificity of construction products as goods 
Thus, construction products in the marketing system can be considered as goods according to the plan of its content (project), goods in real execution (finished object), goods in the form of construction services of a contractor and, finally, goods accompanied by construction products. This is one of the fundamental differences between construction products as goods in comparison with all types of mass or mass production goods that appear on the market in the form of products or their accompaniment during operation.

\section{Innovative activity in the construction industry}

Important for any industry is the concept of «development». The term «development» can be defined as a change in process or phenomenon from simpler to more complex. There are many definitions of enterprise development. But to define the concept of «development» in the construction industry, it is possible to use the definition of development in the economic-production system: development is the process of transition of the system to a new qualitative state due to the accumulation of quantitative potential, changes and complications of structure and composition, resulting in its growth the ability to withstand the effects of environmental factors and improve performance [3].

Information is important for modern enterprise development management because it links and integrates all elements of the organization. The environmental factor is the impetus for the economic growth of the enterprise or the limitation of its capabilities due to the use of harmful technology.

Development of market relations, privatization of state property, reduction of production volumes and conversion have significantly changed the mechanism of management of scientific and technological progress, influenced the pace and nature of innovation as a basis for economic growth, increasing the competitiveness of construction enterprises and organizations.

Innovation in construction is a crucial element in improving production efficiency in a market environment. It provides constant updating and improvement of the used technologies and production of construction products and execution of construction and assembly works, realization of scientific achievements and inventions, is a basic condition for overcoming the industry crisis and ensuring economic growth.

Priority areas for innovative development should be identified in order to effectively innovate in the construction industry (Figure 5). 


\section{Khrystyna Kalashnikova, Viktoriia Shcevchenko}

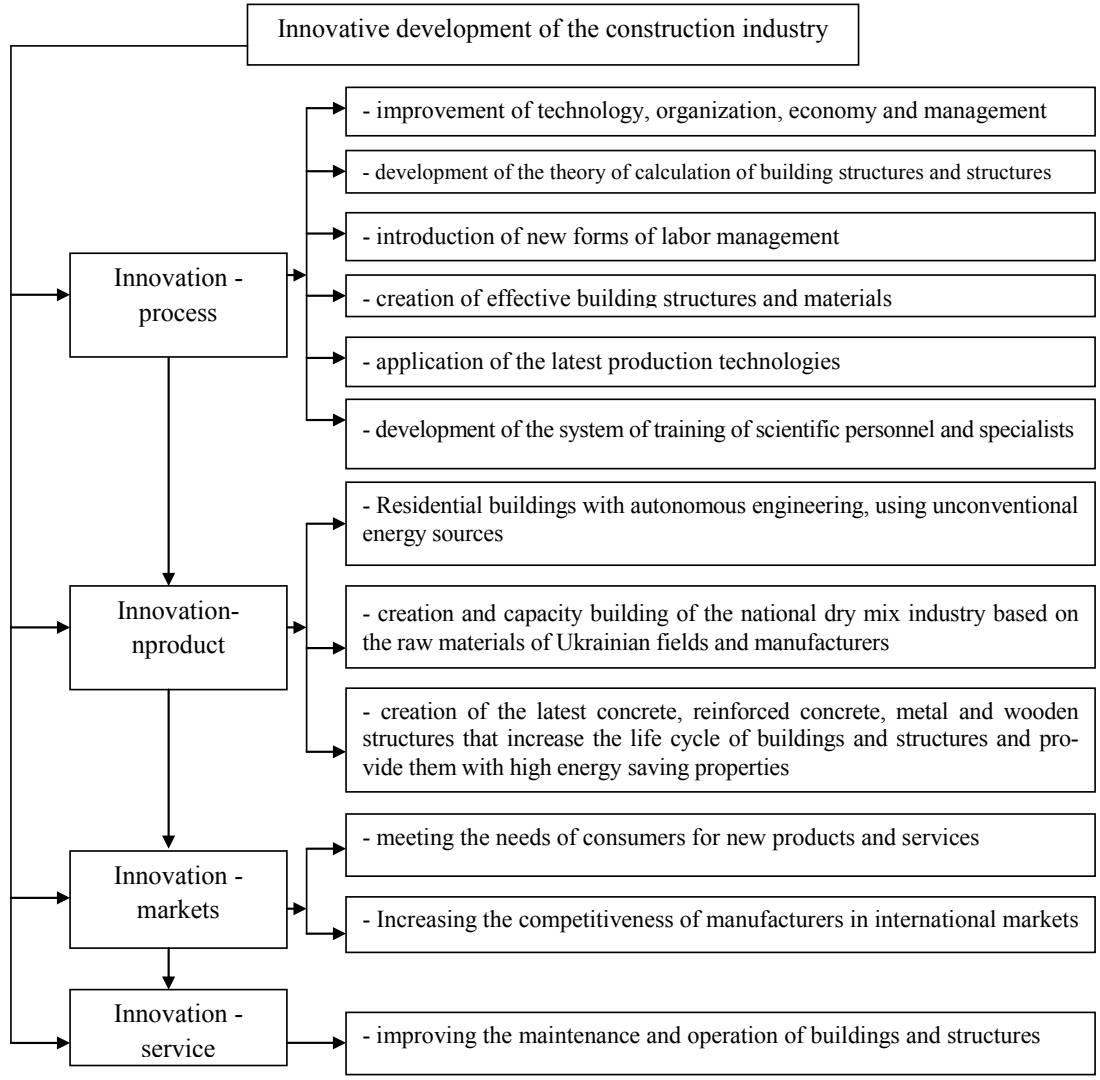

Figure 5. Priority directions of innovative activity of construction industry

It should be noted that innovation in construction is marked by a number of specific features:

- the innovation holds a special place in the construction industry, being the basic factor of economic dynamics, a link between the results of constantly updated construction research;

- the innovation cycle (the period from completion of the research process to implementation in construction) differs in duration (1-5 years) and high risk [2]. 
Implementation of the latest technologies, activation of innovative activity will lead to economic growth not only of the construction industry but also of the state as a whole. To solve the above problems, it is necessary, first of all, to investigate how the financial support of innovative activity of construction enterprises is carried out. In addition to their own funds and the state budget funds, companies should find fundamentally new sources of financing.

It is impossible to innovate without the use of highly qualified staff capable of adapting to new working conditions and wishing to constantly improve and gain new knowledge.

The importance of innovation is mainly determined by the fact that the constant development of science and technology causes the rapid «aging» of production methods, techniques and technologies, products and their quality and technical characteristics, and they need continuous improvement. All this determines the need of the Ukrainian construction industry to innovate. Not only technical innovations should be used, but innovations in management, in particular, of personnel, are of great importance for the functioning of the enterprise.

\section{Specificity of enterprise personnel management in the conditions of in-novative activity}

Virtually all innovative businesses are at high risk. Creating and supporting a healthy climate and positive sentiment is essential for successful innovation. Therefore, the management of the company must not only believe in the new idea, but also convince all staff in the possibility of success, help staff to clearly imagine the prospects of the enterprise in the deepest crisis, to be fully optimistic.

At businesses that follow innovation policies, staff are very sensitive to senior management's attitude to innovation. If staff sees the senior management's indifference to innovation, innovation will be doomed to failure at any further effort and expense. Therefore, the involvement and full involvement of staff in the process of designing and implementing organizational change is so necessary. When any changes are made at the enterprise, it is usually the staff who start to hide them. The very concept of "overcoming resistance to change" suggests that change is happening from above. But few will resist the changes that take place with his involvement. Therefore, the role of the senior level should be not so much the innovator and the 
designer of innovations, but the creator of a favorable innovation environment, providing support and promotion of innovations and changes.

The concept of formation and involvement of staff - the main goal of change in the enterprise, should be directed to its selected part and motivated by the overall vision of the innovation goal.

In general, based on all that has been said, the system of personnel management in construction enterprises in terms of innovation can be represented as follows (Figure 6).

The peculiarity of this system is the humanistic approach to personnel management, which forms innovative-oriented subsystems of personnel management and the concept of formation and involvement of personnel.

An innovative enterprise should use team organizational forms of personnel management. The target teams are thus used in the development and implementation of the restructuring program (as subjects of the innovation process) and as the basic structural units of the future new enterprise. It is the team forms of personnel management that facilitate the rapid and painless diffusion of any innovation, especially organizational. Team forms will allow for high organizational flexibility, significantly expand the range of management and, most importantly, achieve high staff engagement and responsibility.

This creates an innovative climate and the formation of a new organizational culture. Innovative ideas are formed, developed and implemented within a closed circle: target teams - leadership - target teams.

Personnel management systems are being formed in a number of enterprises, which unite, under the sole guidance of the Deputy Director of Personnel Management, all units related to human resources management.

Thus, under the system of personnel management understand a multifaceted and extremely complex process, characterized by its specific features and patterns, which are inherent in the system and completeness on the basis of complex problem solving and their reproduction. It is a systematic, systematically organized influence through interrelated organizational, economic and social measures on the process of formation, distribution, redeployment of personnel at the enterprise level, on the creation of conditions for the use of the work quality of the employee in order to ensure the effective functioning of the enterprise and the full development of its employees. 


\section{Chapter «Economic sciences»}

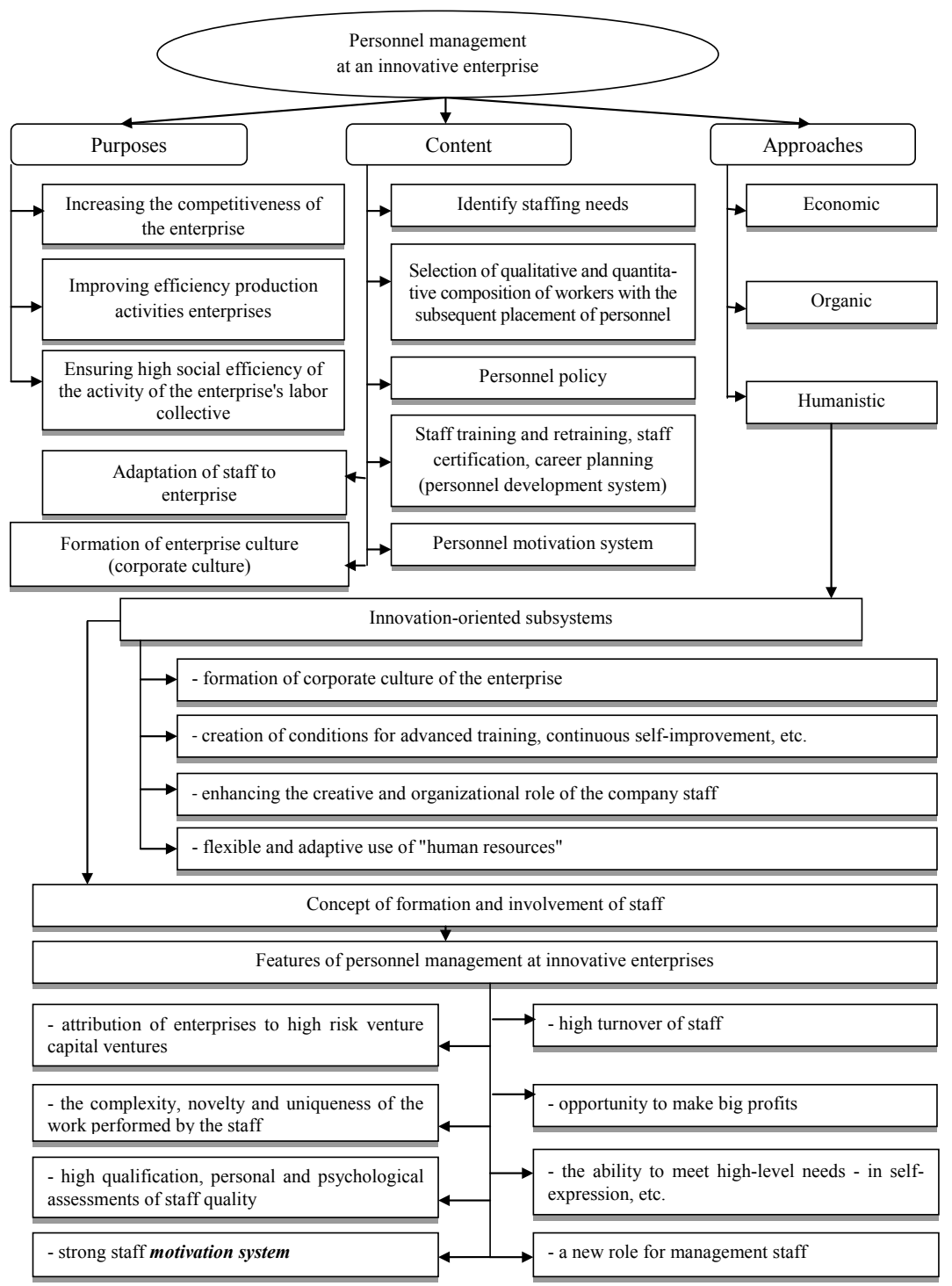

Figure 6. Personnel management system at construction enterprises
in the conditions of innovative activitytry 


\section{Organization of effective personnel management of construction enterprises}

Since labor productivity is determined by the amount of consumer value produced per unit of time, so much of the problem of the expedient work of any worker is reduced to doing only what is necessary (of practical value and can be used internally or externally, whether it is product in material form, any document or other information, service, etc.) in the shortest possible time, that is, in a minimum period of time.

Following this logic, it is necessary to solve two problems: first, how to make every employee's work always necessary, and secondly, how to achieve that the employee at the same time expends working time.

The solution to the first problem is associated with the formation of a system of targeted management of the enterprise (based on the methodology of the strategic management process), when each unit and each employee through the intermediate parameters should be oriented to achieve the ultimate goal of the enterprise. In other words, the work performed by each worker must contribute to the overall result. In this case, the specific work of each employee will always be useful in relation to the interests of the enterprise, which, in turn, must coincide with the interests of society.

The solution of the second problem is conditioned by the expedient work behavior of the employee in relation to the rational use of their working time, including the material condition of solving this task, which is embodied in material labor (means of production) - to interest the employee to keep working time in the performance of their functional duties. However, saving time for each job may not make sense, as the process of manufacturing the finished product or providing services implies synchronous coordination of sequential actions related to the performance of specific work. This agreement is ensured by setting specific deadlines for each specific job, so the process of saving time must be linked to those deadlines by a specific mechanism.

Thus, the scientific foundations of expedient activity of employees of the enterprise are based on the concepts of concrete and abstract labor and the law of time saving, which is implemented in the framework of purposeful management of the enterprise with the inclusion of a mechanism of saving time in the performance of each worker their functions. This mechanism is based on the interest of workers to complete their tasks on time to reconcile 
the chain of interrelated actions. Employee incentive technology should be used to ensure this interest.

Thus, we conclude that the source of expedient work of workers, which ensure the successful functioning of construction enterprises, is to enhance the motivation of specific and abstract work of each employee within the purpose of managing the enterprise and saving working time. In order to achieve this, it is necessary to examine more deeply the organization of effective management of personnel of construction enterprises, presented by Figure 7.

To effectively manage the staff of a construction company, the manager must put forward as a priority the formation of corporate culture, which consists of at least three main parts: the introduction of employees in the mind of the general concept of expedient activities; targeting workers to the end results; use appropriate leadership styles.

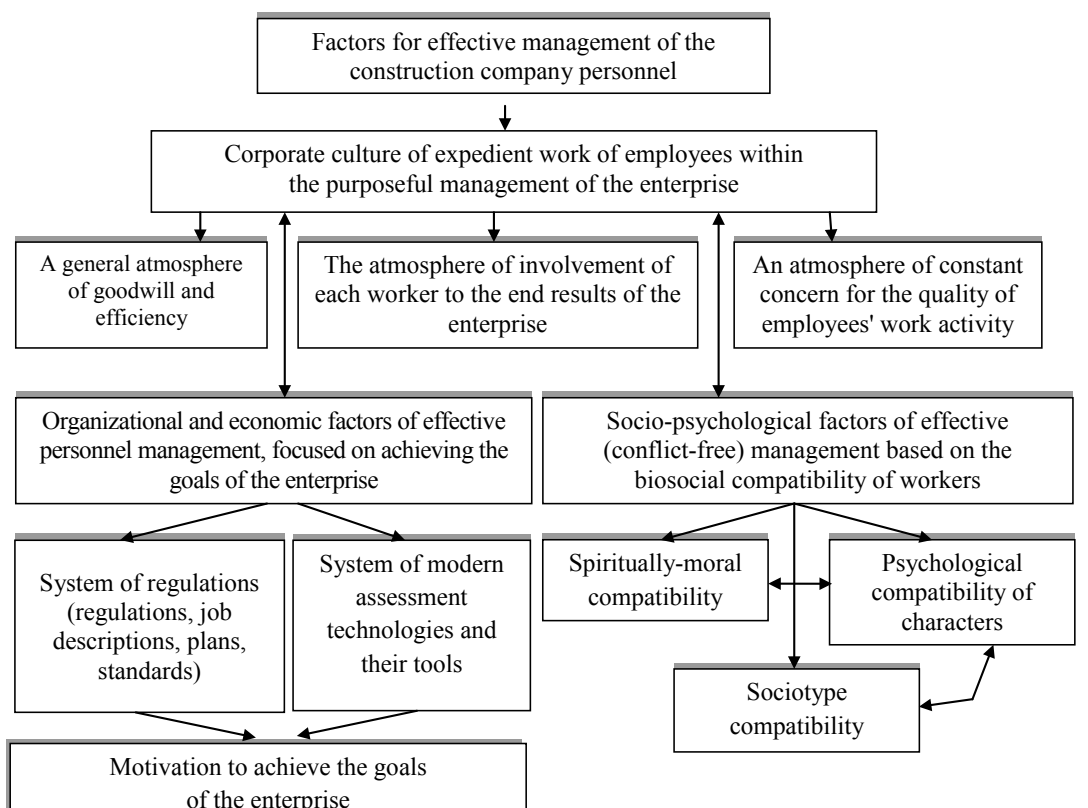

Figure 7. Organization of effective personnel management of construction enterprises 
Creating a favorable climate, or conflict-free management, involves first of all identifying the conditions for such management. These include, first, knowledge of interpersonal relationships that have developed within the team (if not new); second, the study of the personal qualities of workers, which determine their biosocial compatibility; third, the use of the acquired knowledge to control the process of microclimate formation in the team (group) of employees.

Effective management of the personnel of construction enterprises is based on the realization of scientific bases of expedient work of workers, the practical implementation of which leads to the motivated management of the personnel, which is oriented to the achievement of the goals of the enterprise.

The main factor in the expedient work of employees is the corporate culture of expedient work, which is formed at the enterprise through the introduction of certain values in the minds of workers.

The core value to be imparted to the employees of the enterprise is the value of purposeful management, that is, the involvement of each employee to obtain the end result, which depends on the well-being of the enterprise and his personal well-being.

People are the primary means of implementing strategic enterprise manage-ment. Therefore, the system of work with the personnel regarding its activation (personnel management) is considered a priority for the successful functioning of the enterprise.

Establishment of an effective personnel management system, successful choice of concept, motivation, methods and style of management, provision of the enterprise with labor resources, their rational use, high level of labor productivity contribute to increase of production volumes, efficient use of equipment, equipment, machines, mechanisms, cost reduction and projected as a result of the activity of the enterprise and its profit.

\section{Conclusions}

In the article it is proved that the effective process of managing the personnel of the enterprise should be based on taking into account the peculiarities of the sphere of activity of the enterprise, its production and commercial process, the goods and services that are produced and sold. In order to clarify the conceptual provisions of personnel manage- 
ment of construction enterprises, the specifics of the construction industry, construction products and services were investigated. Specificity of the construction industry is: the uniqueness of construction objects; dual nature of construction products: stationary (real estate) and mobile (workplaces and construction machines, mechanisms, equipment, technical and technological equipment of labor); the situation of the construction market, which is caused by complex demand characteristics, on the one hand - for real estate, on the other - for building materials and services; in the significant, important role of the state in the formulation of measures for the promotion of products (state orders (25-50\% of the total volume of construction work) and measures implemented by the state in the framework of fiscal, monetary and monetary policy); cyclical development; the relative slowness of capital turnover, the use of the most progressive types of materials and structures; management of the investment process and its organization; the diversity and the large number of participants in the construction process, from design organizations to real estate maintenance companies. One of the fundamental differences between construction products as a product, in comparison with all types of goods mass or batch production, is that it in the marketing system can be considered as a product in terms of its content (project), product in real performance (finished object), goods in the form of construction services by the contractor and, finally, goods accompanied by construction products. Determining the specificity of the product requires the development of a well-thought commodity policy (proposal) that will be supported by other elements of the marketing mix. Thus, for the development of the construction industry should take into account the interests and needs of all participants in the production and promotion, their relationship. Development must begin at each individual enterprise, bearing in mind that highly skilled and motivated personnel are one of the main reserves of construction enterprises in the production of a complex product. Effective management of individual construction company and the whole industry depends on effective personnel management.

Increasing attention to innovation and innovation processes at all levels of human activity necessitated the study of priority areas for innovative development of the construction industry, the main of 
which are: standardization and normalization in construction, training of highly qualified scientific personnel in the fields of construction, architecture, urban planning and construction materials industry development of new and improvement of existing projects of building structures for buildings and constructions of various purpose, action of ordinary and complex other enerno geological conditions, issues related to eco-Coy development and production of building structures and more. Not only technical innovations but also innovations in management, in particular, of personnel, should be used. The introduction of innovative methods of personnel management will allow the construction company to provide more volume and quantity of innovations in production, at the expense of more efficient use of potential, knowledge and skills of own personnel.

Awareness of the need to improve the process of personnel management of construction enterprises has led to the need to analyze existing approaches and concepts of personnel management. The analysis made it possible to propose the author's system of personnel management of construction enterprises in terms of innovative activity, which is based on a humanistic approach to personnel management.

The structural model of the organization of effective management of personnel of the construction organization is constructed. At the same time, it is determined that for effective management of the personnel of a construction company, the manager must put forward as a priority the formation of a corporate culture, which consists of at least three main parts: the introduction of employees in the mind of the general concept of expedient activities; Targeting workers to the end results; use appropriate leadership styles.

It is proved that building an effective personnel management system, successful choice of concept, motivation, methods and management style, providing the enterprise with labor resources, their rational use, high level of labor productivity contribute to the increase of production volumes, efficient use of equipment, equipment, machines, mechanisms, reduction cost and is projected on the result of the enterprise and profit. It is this system of personnel management of the construction company that should lead to an increase of innovative activity of the enterprise itself. 


\section{References:}

1. Ansoff Y. (1989). Stratehycheskoe upravlenye [Strategic management]. Moscow: Ekonomyka. (in Russian)

2. Arkhypov A., Horodetskyi A., Mykhailov B. (1994). Ekonomycheskaia bezopasnost: otsenky, problems, sposobs obespechenyia [Economic security: assessments, problems, ways of ensuring]. Voprosu ekonomyky, no. 12, pp. 36-44.

3. Achkasov A.Ye. (2004). Osnovi stratehyy rehulyrovanyia zaniatosty naselenyia Ukrayni (teoryia y praktyka) [Fundamentals of the strategy for regulating the employment of the population of Ukraine (theory and practice] (PhD Thesis). Kharkiv: KhNU.

4. Bazhan I.I. (2004). Orhanizatsiino-ekonomichnyi mekhanizm derzhavnoho rehuliuvannia efektyvnoho vykorystannia trudovoho potentsialu Ukrainy [Organizational and economic mechanism of the sovereign regulation of the effective labor potential of Ukraine]. (PhD Thesis). Kiev: KNEU.

5. Bazarova T.Yu., Eremyna B.L. (2002). Upravlenye personalom [Personnel Management]. Moscow: YuNYTY. (in Russian)

6. Bazarova T.Yu., Malynovskyi P.V. (1998). Upravlenye personalom v uslovyiakh kryzysa [HR management in a crisis]. Moscow: YuNYTY. (in Russian)

7. Borysov A.B. (2000) Sovremennaia kontseptsyia upravlenyia kadramy predpryiatyia $\mathrm{v}$ uslovyiakh rynochnoi ekonomyky [The modern concept of enterprise personnel management in a market economy]. Menedzhment $v$ Rossyy $y$ zarubezhom, no. 5, pp. 111-115.

8. Vasylenko V.A. (2005). Dyahnostyka ustoichyvoho razvytyia predpryiatyi. [Diagnostics of sustainable development of enterprises]. Kiev: TsUL. (in Ukrainian)

9. Vasylchenko V.S., Hrynenko A.M., Hrishnova O.A., Kerb L.P. (2005). Upravlinnia trudovym potentsialom [Workforce Management]. Kiev: KNEU. (in Ukrainian)

10. Hlevatska N.M. (2006). Konkurentospromozhnist robochoi syly rehionu : metodolohiia ta napriamy zabezpechennia [Competitiveness of the region's workforce: methodology and lines of support]. (PhD Thesis). Kirovohrad: KDU. (in Ukrainian)

11. Holenko D.Y. (1986). Statystycheskye metody setevoho planyrovanyia y upravlenyia [Statistical methods of network planning and management]. Moscow: Nauka. (in Russian)

12. Horbunov V.M. (1998). Upravlinnia sotsialnym rozvytkom trudovoho kolektyvu [Management of social development of labor collective]. Kiev: MAUP. (in Ukrainian)

13. Hrabovyi P.H., Petrova S.N. (1994). Rysky v sovremennom byznese [Risks in modern business]. Moscow: Alane. (in Russian)

14. Hrishnova O.A. (2001). Liudskyi kapital: formuvannia v systemi osvity i profesiinoi pidhotovky [Human capital: formation in the system of education and training]. Kiev: Znannia. (in Ukrainian)

15. Zalunyn V.F., Mladetskyi V.R. (1996). Analyz dynamycheskykh kharakterystyk protsessa upravlenyia [Analysis of the dynamic characteristics of the control process]. Upravlenye stroytelnymy proektamy, no. 1, p. 156. 
16. Zalunyn V.F., Mladetskyi V.R. (1996). Teoretycheskye aspekty dyversyfykatsyy stroytelnoho proyzvodstva [Theoretical aspects of diversification of building production]. Upravlenye stroytelnymy proektamy, no. 1, p. 156.

17. Kravtsova T.O. (2003). Orhanizatsiia upravlinnia personalom [Organization of personnel management]. Kharkiv: KhDEU. (in Ukrainian)

18. Kryklii A.S. (2005). Teoretyko-metodolohichni osnovy doslidzhennia trudovoho potentsialu [Theoretical and methodological foundations of the study of labor potential]. Ekonomika ta derzhava, no. 8, pp. 61-67.

19. Ladanov Y.D., Pronnykov V.A. (1987). Chelovecheskyi faktor v khoziaistvennom upravlenyy [The human factor in economic management]. Moscow: Znanye. (in Russian)

20. Torkatiuk V.Y., Dmytruk Y.A., Stadnyk H.V. (2004). Optymyzatsyia upravlenyia protsessom deiatelnosty stroytelnoho predpryiatyia : monohrafyia [Optimization of the process management of a construction enterprise: a monograph]. Kharkiv: KhNAHKh. (in Ukrainian)

21. Pyzh N.S. (2010). Formuvannia efektyvnoi systemy motyvatsii trudovoi diialnosti na pidpryiemstvakh budivelnoi haluzi [Formation of an effective system of motivation of work activity in the enterprises of the construction industry]. ( $\mathrm{PhD}$ Thesis). Kharkiv: KhNU.

22. Rudchenko O., Ponomarova O. (2002). Pidvyshchennia efektyvnosti vykorystannia trudovoho potentsialu na pidpryiemstvakh riznykh form vlasnosti $\mathrm{v}$ umovakh rozderzhavlennia [Increasing the efficiency of the use of labor potential in enterprises of different forms of ownership in conditions of privatization]. Ukraina : aspekty pratsi, no. 1, pp. 35-39.

23. Saienko M. (2002). Trudovyi potentsial: osnovni vyznachennia i nekorektni formuliuvannia [Labor potential: basic definitions and incorrect formulations]. Visnyk Ternopilskoi akademii narodnoho hospodarstva, no. 6, pp. 71-76.

24. Seniv B.H. (2011). Suchasnyi stan ta perspektyvy rozvytku budivelnoi haluzi Ukrainy [The current state and prospects of development of the construction industry of Ukraine]. Innovatsiina ekonomika, no 7, pp. 19-24.

25. Solntseva N.V. (2012). Otsiniuvannia ta rehuliuvannia orhanizatsiinoi kultury budivelnykh pidpryiemstv [Assessment and regulation of organizational culture of construction enterprise]. PhD Thesis. Kharkiv: KhNU.

26. Sokolova L.V., Kovalevska A.V., Oksenenko S.P., Radchenko N.A. (2011). Upravlinnia personalom promyslovykh pidpryiemstv (mezo-ta mikroriven): monohrafiia [Management of personnel of industrial enterprises (meso and micro levels): monograph]. Kharkiv: Kompaniia SMIT. (in Ukrainian)

27. Shumpeter Y.A. (1982). Teoryia ekonomycheskoho razvytyia (Yssledovanye predprynymatelskoi prybyly, kapytala y tsykla konjiunktury); per. s nem. [Theory of economic development (Study of entrepreneurial profit, capital and the business cycle)]. Moscow: Prohress. (in Russian)

28. Shlenov Yu.V. (2003). Upravlenye ynnovatsyiamy. Bazovye komponenty upravlenyia ynnovatsyonnymy protsesamy [Innovation management. Basic components of process management]. Moscow: Vysshaia shkola. (in Russian) 